\title{
Awareness Completes Brand Loyalty: Reality of Zimbabwe Tourism Destination
}

\author{
Farai Chigora (Corresponding author) \\ Faculty of Commerce, Catholic University of Zimbabwe, Zimbabwe \\ E-mail: fchigora@yahoo.com Tel: 263-772-886-871 \\ Promise Zvavahera \\ National University of Science and Technology, Zimbabwe \\ E-mail: promisezvavahera59@gmail.com Tel: 263-773-471-703
}

Received: July 31, 2015 Accepted: August 25, 2015 Published: November9, 2015

doi:10.5296/bmh.v3i2.8547ＵRL: http://dx.doi.org/10.5296/bmh.v3i2.8547

\begin{abstract}
The study investigated the supremacy of raising tourism destination awareness in improving brand loyalty. This was based on the fact that Zimbabwe as a tourism destination has received global awareness through various campaigns but still failing to improve its tourism destination brand loyalty. Therefore the study applied both a positivists and interpretivist's paradigm using quantitative and qualitative research designs respectively. Sequentially the research design started with a qualitative approach whereby senior managers in the tourism industry were interviewed and agreed that the most common sources of brand loyalty are brand awareness, brand image and perceived brand quality. These variables were then investigated on their relationship to brand loyalty using survey questionnaires that were distributed to the three main sectors of the tourism industry namely accommodation, travel and resorts. The results of the study showed that brand image is the most dominant variable which needs to be uplifted in order to improve Zimbabwe tourism destination's brand loyalty. This is then followed by brand awareness and perceived brand quality. It is when there is an acceptable image of the Zimbabwe's tourism brand that positive brand awareness will be created and perceived quality will be enhanced in moment of truth experiences. The study recommended an intensive media campaign to change the current negative perception on Zimbabwe as a tourism destination and sponsored familarisation tours. Also the study recommended an effective evaluation of the tourism products and services in order to see if they are of required quality and an intensive stakeholder involvement in brand formulation.
\end{abstract}


Keywords: brand awareness, brand loyalty, brand image, tourism destination, Zimbabwe, perceived brand quality 


\section{Introduction}

Awareness has been regarded as a key element of brand equity variables (Keller, 2013; Aaker, 1991). The reason for considering brand awareness in brand equity creation can be pointed to publicity creation and triggering the mind of the consumers about the existence of a certain service or product in the market. It is the initial requisite in creating brand knowledge and identity such that the brand stays in the mind of the customers under any condition (Keller, 1993). Tourism destinations have been transformed to brands which are identified and positioned on the global market based on their performance. The performance of a brand can be measured by the loyalty it has gained from customers in the market. According to Aaker (1991) brand loyalty is about constructing a mind that will eventually lead to a purchase by the consumer. Yoo (2000) concurred by acknowledging that brand loyalty makes the customer repeat purchasing the same product and considering it first from competing brands. This means that a good performing brand will have high customer loyalty and an underperforming brand will have a weak customer loyalty. Zimbabwe tourism destination brand has failed to perform in the previous years due to many factors and amongst the economic downfall. This can be seen from the negative views that have been published in various media platforms globally discouraging touristic activities in Zimbabwe. Destination in marketers have used various channels in trying to restore a better status quo for the industry but the position of the tourism destination is still at a low level at the world market. Historically, Zimbabwe has been an attractive destination as it received many visitors around the globe especially in the 1980s and 1990s. However, the industry faced a major slump from year 2000 going forward. These efforts that have been made by the country's tourism destination marketers spearheaded by Zimbabwe Tourism Authority included branding as a major strategic tool amongst other promotions like expos showcasing, indabas, carnivals and institutionalized collaborations. The Zimbabwean government has supported the tourism sector through various mechanisms as it has been regarded as a strengthening pillar for economic transformation and growth. This has seen the sector being included in the country's economic driver blue print known as the Zimbabwe Agenda for Sustainable Socio-Economic Transformation (ZIMASSET). Awareness has been raised on the existence of the Zimbabwe tourism brand like the showcasing of the current "Zimbabwe A World of Wonders" in other countries like Brazil (Chibaya, 2013). This effort has not yet transformed into completeness as the country's tourism brand loyalty is still low. The study therefore investigated on the supremacy of brand awareness in improving tourists' loyalty to Zimbabwe as a tourism destination.

\section{Problem Statement}

Zimbabwe as a tourism destination has received a high global awareness but still failing to gain its previous position as an attractive place of visit. The years after independence between 1980 and 1999 saw a vibrant performance of the tourism industry (Chibaya, 2013; Ndlovu \& Heath, 2013). However, the years after 2000 witnessed a major downfall of the tourism sector. Awareness has been raised intensively but the country's tourism destination still not gaining its glamour like in the years after independents. Various brand awareness campaigns including carnivals, host of international conferences and others have been staged in order to 
raise awareness for Zimbabwe tourism destination (Chibaya.2013). The study therefore investigated the superiority of awareness in improving Zimbabwe tourism destination brand loyalty.

\section{Literature Review}

Brand awareness is a significant reflection of how consumers know a brand looking mainly at the strength of brand presence in the mind of consumers and how this knowledge can be easily retrieved from the mind or memory of the consumer (O'Guinn, Allen, \& Semenik, 2009). Farquhar's (1989) approached brand awareness as the quickness to which a customer can retrieve the elements of a brand stored in his or her memory overtime. Tourism destination like general products can measure their level of awareness as postulated by Mowen \& Minor (2001) who said brand awareness is the ability of a customer to retrieve in mind the existence of a certain product amongst other products. A destination that is well known will be visited more than that of competitors. When a product or service has a high awareness it means that it carries a good repute and the market simply accept it (Gustafson \& Chabot, 2007). Brand awareness is centered on brand recognition which happens when a customer has once seen the brand and brand recall which is the ability of the customer to name a certain brand when exposed to a product category at any given point in time (Liu, Liston-Heyes \& Ko 2010). Tourism destinations can be known as groups existing in a certain region but within these regions some can be pointed and selected by the superiority of their brands. The concept of brand awareness is one of the amalgams that make up brand equity (Gartner \& Ruzzier, 2011). Keller (2013) denoted that brand awareness forms the first stage in building the brand equity of a product or service. According to Aaker (1991) the fundamental brand equity variables can be sequentially reckoned as brand awareness, perceived brand quality, brand loyalty and brand association. This suggests that brand awareness has been regarded as the foundation of creating vibrant brand equity. Farris et al. (2010) pointed that there are two main types of brand awareness namely top of the mind awareness and added awareness with the former entailing that the customer associate with a particular product category and the later meaning that when given a variety of brands a consumer can be able to pick a certain one with a known brand. Destination brands can also be distinguished into that carrying top mind awareness or an added awareness. Brand awareness is important in tourism destinations because a place should be known for it to receive visitors at any given point in time (Gartner \& Ruzzier, 2011). This means that the survival of any destination on the global market is improved through visual improvement of symbols and images in an effort to create awarenes (Im, Kim, Elliot, \& Han, 2012). Effective brand awareness helps in improving the sale of a company emanating from the ability to convince customers to buy the product or do a repeat purchase (McKee, 2010). This can be appreciated in a tourism destination when a tourist is made aware on its existence and store the knowledge in his or her mind for a long time such that when the need for a holiday comes, the mind will direct the tourist to the same destination stored in the memory. Homburg, Klarmann and Schmitt (2010) investigated the impact of brand awareness to the performance of an organisation and discovered that there is a relationship between brand awareness and market outcome together with brand loyalty and the marketing mix. Huang and Sarigollu 
(2012) also carried a study on the relationship between brand awareness and the market performance and pointed that there is a need to further investigate on how brand awareness affect brand loyalty. Pitta and Katsanis (1995) argued that brand awareness can be created in the consumer's mind before brand association takes place. This means that it is when a tourist is made aware of a tourism destination that the desire to associate with its brand is then triggered. In order to understand the crucial role that is played by brand awareness as the foundation of brand equity, Keller (2001) produced a brand knowledge pyramid as shown in figure 1 below:

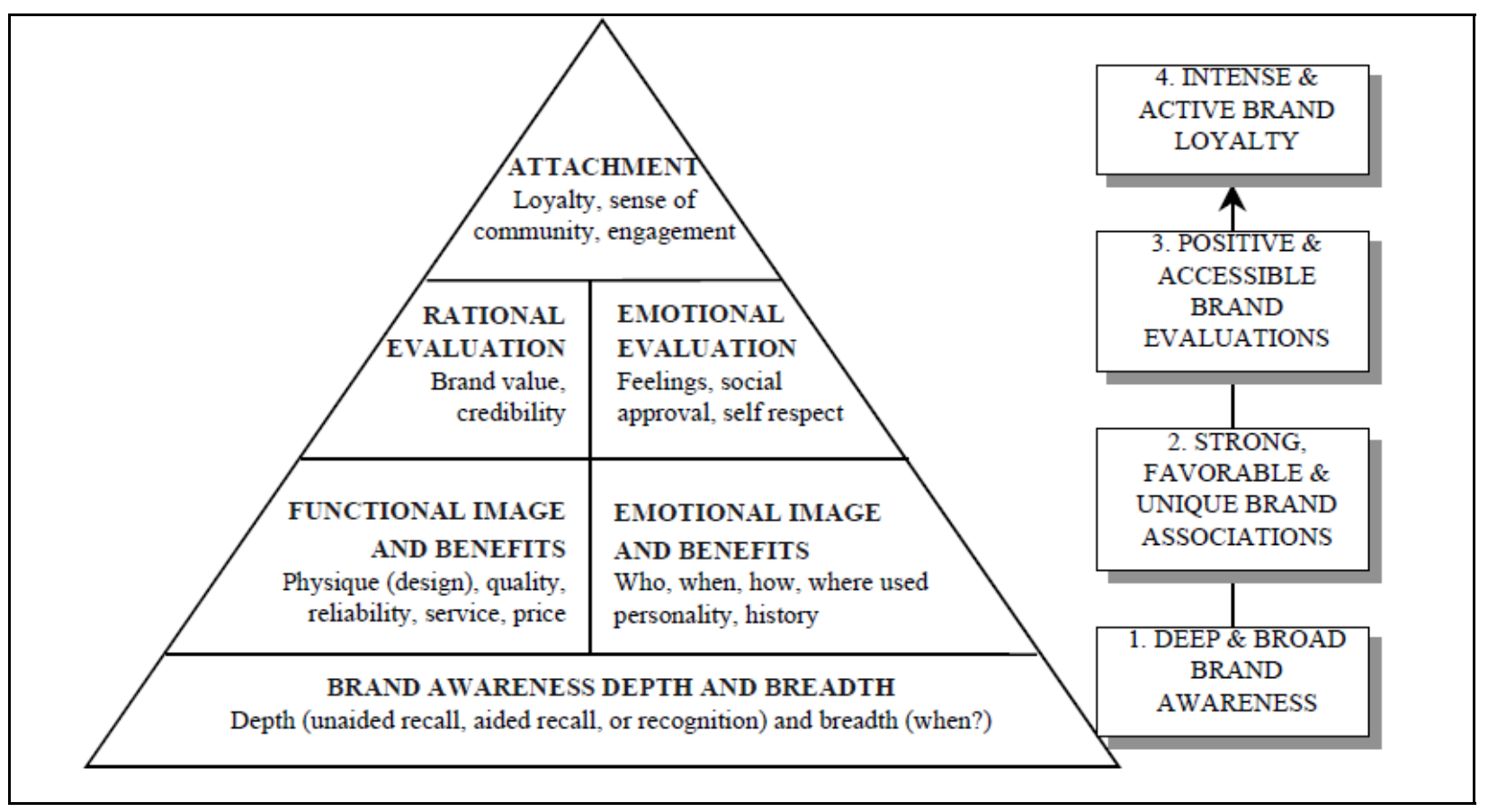

Figure 1. Brand knowledge pyramid

Source: Keller (2001).

According to Keller (2001) as shown in figure 1 above, brand awareness forms the basis of customer brand knowledge. This is the ability to recall a brand by the consumers at any point of purchase. Positive knowledge about a brand can be seen from the level they patronize its offerings. Awareness is not always positive meaning that a tourism destination can have high level of awareness but in a negative form (Gartner \& Ruzzier, 2011). Some most well known destinations in the world have grown in popularity from the negative attributes the carry for example known because of wars and other risky events. Media publicity has therefore helped in creating positive awareness for various destinations. Awareness for Zimbabwe tourism destination has been mainly on socio-economic and political issues that have even destroyed the brand image of the country (Ndlovu \& Heath, 2013). Brand awareness has an influence on brand image of a destination. Zimbabwe tourism brand is however not showing the signs of positive awareness. This is because with effort that has been done to create high levels of awareness still tourists are not frequenting their visits compared to other glamorous years. 


\section{Ml Macrothink}

Business and Management Horizons

ISSN 2326-0297

2015, Vol. 3, No. 2

The question therefore revolve on the need to understand if it is about awareness or other brand equity elements that can rejuvenate a tourism destination brand in this case looking at Zimbabwe. Literature gaps shows that there is a sequential treatment of the brand equity variables yet the brand development stages can differ for each tourism destination at any given point in time.

\section{Methodology}

The research was based on a positivists and interpretivist paradigm. This made the research design both deductive and inductive as a quantitative and qualitative approach (mixed methods). The respondents for the research came from the three main sectors of the tourism industry namely accommodation, travel and resorts established using stratified random sampling. The total population for the research was 115 made of 45 from accommodation sector, 55 from the travel sector and 15 from resorts. In-depth interviews were made as a qualitative approach in order to find the most common sources of brand loyalty from experts in the Zimbabwe tourism and hospitality industry. These were later investigated on their effect to brand loyalty using survey questionnaires as a quantitative research design. Data analysis was done using average mean statistics ranging from 1 to 5 ( 1 = Strongly agree and $5=$ Strongly disagree). The average means where then presented in the form of a table and pie chart.

\section{Findings and Discussions}

The research constructed the most common elements of tourists' brand loyalty using qualitative means through in-depth interviews and concluded that they are made up of brand awareness, brand image and perceived brand quality. These variables were then statistically analysed on their dominance in the Zimbabwe tourism destination's brand loyalty and the findings are as shown in table 1 below.

Table 1. Responses on the sources on brand loyalty in Zimbabwe tourism destination

\begin{tabular}{|l|l|l|l|}
\hline Respondents Sectors & $\begin{array}{l}\text { Awareness and Brand } \\
\text { Loyalty }\end{array}$ & $\begin{array}{l}\text { Image and Brand } \\
\text { Loyalty }\end{array}$ & $\begin{array}{l}\text { Perceived Quality and } \\
\text { Brand Loyalty }\end{array}$ \\
\hline & (Average mean) & (Average mean) & (Average mean) \\
\hline Accommodation & 1.257 & 1.167 & 2.103 \\
\hline Travel & 2.314 & 1.064 & 2.333 \\
\hline Resorts & 1.971 & 2.131 & 2.11 \\
\hline Total Average Mean & $\mathbf{1 . 8 4 7}$ & $\mathbf{1 . 4 5 4}$ & $\mathbf{2 . 1 8 1}$ \\
\hline
\end{tabular}

Note. The average mean are in a range of 1-5 (1= Strongly Agree; 5=Strongly Disagree).

Source: Research Survey (2015). 


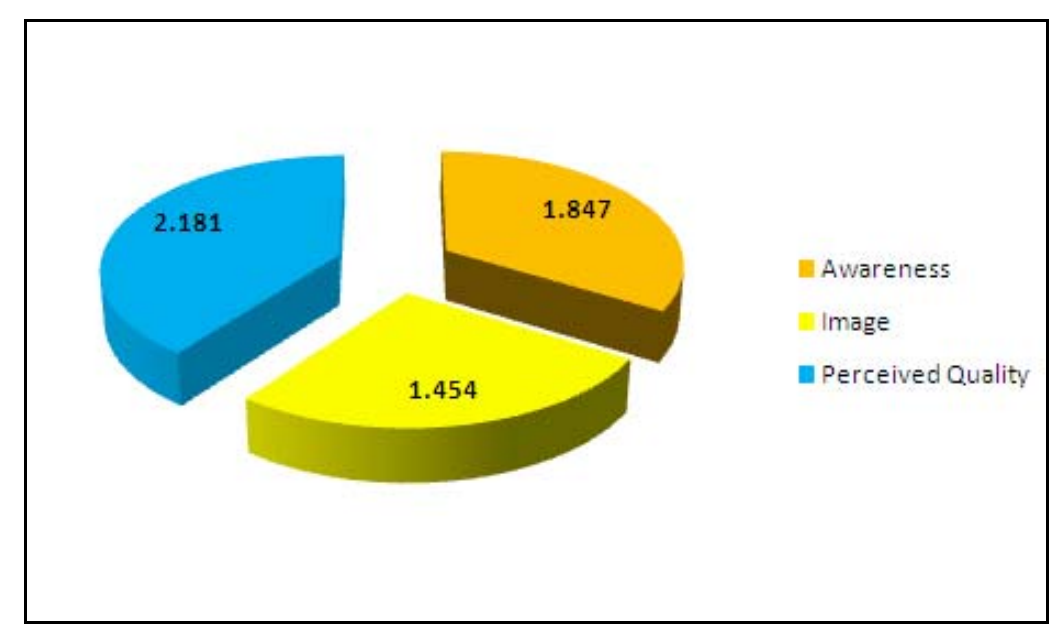

Figure 1. Responses on the sources on brand loyalty in Zimbabwe tourism destination

Source: Research Survey (2015).

The findings presented in table 1 and figure 1 below shows that brand awareness, brand image and perceived quality have an average mean of 1.847, 1.454 and 2.181 respectively. These statistics informs that Zimbabwe's tourism brand loyalty is mainly centered on its image (1.454) rather than brand awareness and perceived quality. According to the brand knowledge presented by Keller (2001), brand image can be grouped into functional image and benefits and emotional image and benefits. The Zimbabwe tourism destination authorities should therefore assess on the most dominant type of image that needs to be addressed so as to improve tourists' loyalty for Zimbabwe tourism brand. The image might be in the form of the country's history, its pricing, its politics or any other variables. According to Ndlovu \& Heath (2013) Zimbabwe tourism destination's brand image has suffered from negative socio-economic and political that transpired in the country. This therefore calls for tourism authority to counter any negative publicity associated which these events that has destroyed the country's image using various modes including media and other public announcements. Awareness and loyalty reveals a second lowest average mean (1.847) showing that there is also a greater relationship between Zimbabwe tourism destination brand loyalty and brand awareness. This can be related to image in a sequential way by revealing that the first section that need to be resolved in destination Zimbabwe is its brand image. This will be reinforced by positive brand awareness so that the created good image is spread to the world and remain in the memory of traditional and prospective tourists forever. Perceived quality had a the highest average mean (2.181) showing that it does not have an instant direct relationship with brand loyalty but it is more of a perception that is enhanced by first having an improved image then created awareness. Quality by its nature is highly subjective meaning that it is hard to measure on its impact to brand loyalty. 


\section{Recommendations}

Zimbabwe tourism destination marketers should invest in intense positive image creation campaigns. Media should be considered as a key tool that can reinforce positive image. This is because a well crafted tourism media policy can improve positive publicity internationally.

There is a need to make an evaluation on the quality of tourism products and services that are offered in the Zimbabwe tourism destination. This helps in improving the perception of the tourists on the quality. When there is a high a perceived quality, tourist will become loyal and will eventually purchase the tourism products and services.

Awareness can reap positive brand loyalty if it is crafted considering the crucial stakeholders. The main stakeholders in a tourism destination are marketers and the tourists. If there is an integrated effort of marketing partners, they will have an effective awareness mix that can convince a reach all tourists and result in them buying. Also a knowing what tourists want in a destination will help in promoting awareness based on the specific variable that lead to consumption.

The authorities in Zimbabwe tourism destination should set a budget for sponsored familarisation tours. These can be extended to various players in information publicity. They include travel writers, civil bodies, travel agency and political bodies of other countries. This is because a tour of the country will help provide a real moment of truth that can be uses to spread positive news to others.

\section{Conclusion}

The reality on the ground shows that awareness on its own does not lead to an improved brand loyalty. Awareness can be regarded as the first step towards achieving brand loyalty. This is because knowing the existence of a destination does not eventually lead to a desire to consume the tourism products and services. The offerings of that tourism destination will are the main drivers to consumption. Tourists will consider the image of a destination and the quality of its offerings and when they are satisfied, they become loyal. Zimbabwe tourism destination has raised its awareness from the negative image associated with its socio-economic and political misfortunes. This has affected its image such that tourist have not been loyal to the destination over the years.

\section{References}

Aaker, D. A. (1991). Managing Brand Equity: Capitalizing on the Value of a Brand.

Chibaya, T. (2013). From 'Zimbabwe Africa’s Paradise to Zimbabwe A World of Wonders': Benefits and Challenges of Rebranding Zimbabwe as A Tourist Destination. Developing Country Studies, 13(5), 84-91.

Farquhar, P. H. (1989). Managing Brand Equity. Journal of Marketing Research, 1.

Farris, P. W., Bendle, N. T., Pfeifer, P. E., \& Reibstein, D. J. (2010). Marketing metrics: The definitive guide to measuring marketing performance. Upper Saddle River, NJ: Pearson. 


\section{Macrothink}

Business and Management Horizons

ISSN 2326-0297

2015, Vol. 3, No. 2

Gartner, W. C., \& Ruzzier, M. K. (2011). Tourism Destination Brand Equity Dimensions: Renewal versus Repeat Market. Journal of Travel Research, 50(5), 471-481.

Gustafson, T., \& Chabot, B. (2007). Brand Awareness. Cornell Maple Bulletin, 105.

Homburg, C., Klarmann, M., \& Schmitt, J. (2010). Brand awareness in business markets: When is it related to firm performance? International Journal of Research in Marketing, 27(3), 201-212. http://dx.doi.org/10.1016/j.ijresmar.2010.03.004

Huang, R., \& Sarigöllü, E. (2012). How brand awareness relates to market outcome, brand equity, and the marketing mix. Journal of Business Research, 65, 92-99. http://dx.doi.org/10.1016/j.jbusres.2011.02.003

Im, H. H., Kim, S. S., Elliot, S., \& Han, H. (2012). Conceptualizing Destination Brand Equity Dimensions from a Consumer-Based Brand Equity Perspective. Journal of Travel \& Tourism Marketing, 29, 385-403.

Keller, K. L. (1993). Conceptualizing, Measuring, and Managing Customer-Based Brand Equity. Journal of Marketing, 57(1).

Keller, K. L. (2013). Strategic management: building, measuring and managing brand equity, fourth Edition. England: Pearson Education Limited.

Liu, G., Liston-Heyes, C., \& Ko, W. W. (2010). Employee participation in cause-related marketing strategies: A study of management perceptions from British consumer service industries. Journal of Business Ethics, 92, 195-210. http://dx.doi.org/10.1007/s10551-009-0148-3

McKee, S. (2010). Creative b2b branding: Building a creative brand in a business world. Goodfellow, America.

Ndlovu, J., \& Heath, E. (2013). Re-branding of Zimbabwe to enhance sustainable tourism development: Panacea or Villain. Academic Journals, 1(12), 947-955.

O’Guinn, T. C., Allen, C. T., \& Semenik, R. J. (2009). Advertising and integrated brand promotion (5th ed.).

Pitta, D. A., \& Katsanis, L. P. (1995). Understanding brand equity for successful brand extension. Journal of Consumer Marketing, 51. http://dx.doi.org/10.1108/07363769510095306

Yoo, B., Donthu, N., \& Lee, S. (2000). An examination of selected marketing mix elements and brand equity. Journal of the Academy of Marketing Science, 28(2), 195-211. 


\section{Copyright Disclaimer}

2015, Vol. 3, No. 2

Copyright for this article is retained by the author(s), with first publication rights granted to the journal.

This is an open-access article distributed under the terms and conditions of the Creative Commons Attribution license (http://creativecommons.org/licenses/by/3.0/). 